LA-13733-PR

Progress Report

Approved for public release;

distribution is unlimited.

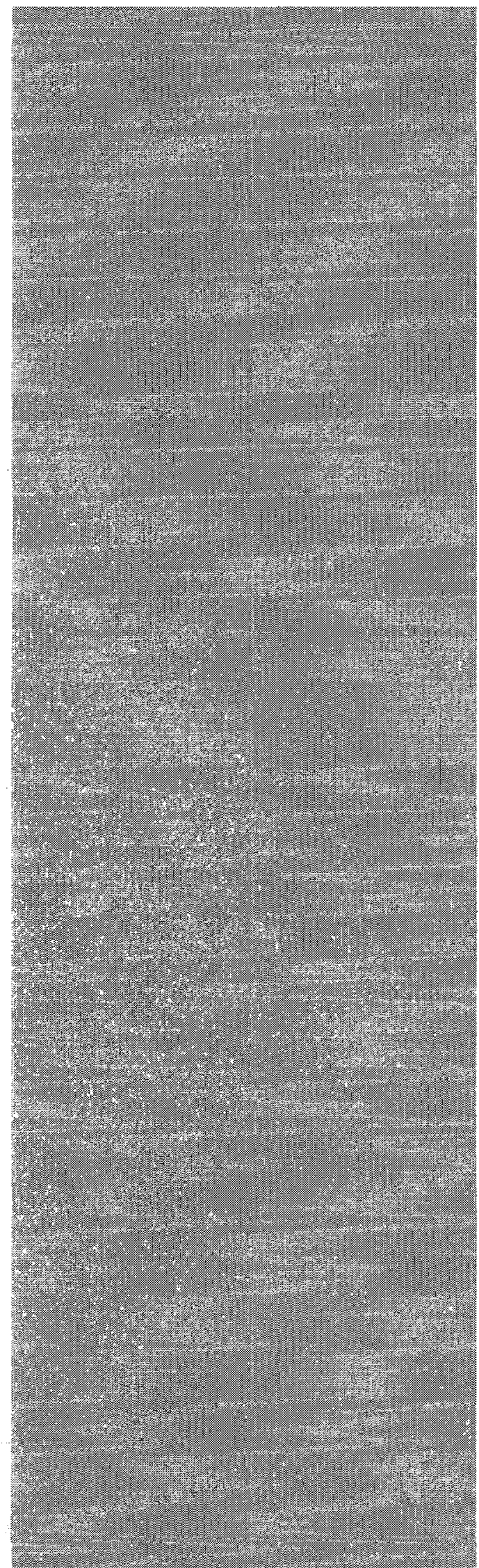

Radionuclide Concentrations in Honey Bees from Area G at TA-54 during 1999

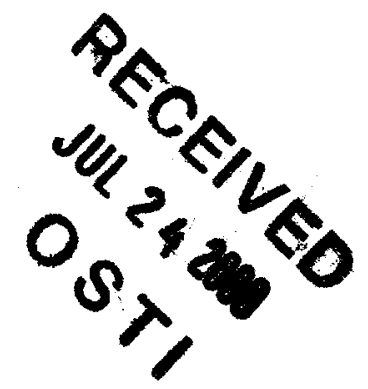

\section{Los Alamos}

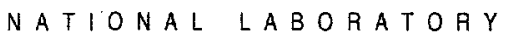

Los Alamos National Laboratory is operated by the University of California for the United States Department of Eneroy under contract W-7405-ENG-36. 
The two most recent reports in this unclassified series are $L A-13480-P R$ and LA-13613-PR.

Edited by Hector Hinojosa, Group CIC-1

Prepared by Teresa Hiteman, Group ESH-20

An Affirmative Action/Equal Opportunity Employer

This revort was prepared as an account of work sponsored by an agency of the United States Government. Neither The Regents of the University of California, the United States Government nor any agency thereof, nor any of their employees, makes any warranty, express or implied, or assumes any legal liability or responsibility for the accuracy, completeness, or usefulness of any information, apparatus, product, or process disclosed, or represents that its use would not infringe privately owned rights. Reference herein to any specific commercial product, process, or service by trade name, trademark, manufacturer, or otherwise, does not necessarily constitute or imply its endorsement, recommendation, or favoring by The Regents of the University of California, the United States Government, or any agency thereof. The views and opinions of authors expressed herein do not necessarily state or reflect those of The Regents of the University of California, the United States Government, or any agency thereof. Los Alamos National Laboratory strongly supports academic freedom and a researcher's right to publish; as an institution, however, the Laboratory does not endorse the viewopoint of a publication or guarantee its technical correctness. 
Radionuclide Concentrations in Honey Bees from Area $G$ at TA-54 during 1999

T.K. Haarmann

P.R. Fresquez 


\section{DISCLAIMER}

Portions of this document may be illegible in electronic image products. Images are produced from the best available original document. 


\title{
RADIONUCLIDE CONCENTRATIONS IN HONEY BEES \\ FROM AREA G AT TA-54 DURING 1999
}

\author{
T.K. Haarmann and P.R. Fresquez
}

\begin{abstract}
Honey bees were collected from two colonies located at Los Alamos National Laboratory's Area G, Technical Area 54, and from one control (background) colony located near Jemez Springs, NM. Samples were analyzed for various radionuclides. Area $\mathbf{G}$ sample results from both colonies were higher than the upper $(95 \%)$ level background concentration for ${ }^{3} \mathrm{H}$. Sample results from one colony were higher than the upper $(95 \%)$ level background concentration for total uranium, while sample results from the other colony were higher than the upper $(95 \%)$ level background concentration for ${ }^{90} \mathrm{Sr}$.
\end{abstract}

\section{INTRODUCTION}

As part of the ongoing environmental surveillance program at Area G (Fresquez et al. 1997a)—a 25.5ha $(63-a c)$ low-level radioactive waste management and disposal area located on the east end of Mesa del Buey at Technical Area 54 at Los Alamos National Laboratory (LANL) (Figure 1)-samples of honey bees were collected from beehives during the fall of 1999. Honey bees can be thought of as mobile samplers that efficiently cover a large sample area and then return to a central location (Bromenshenk 1992). Honey bees forage in an area with a radius as large as $6 \mathrm{~km}(3.7 \mathrm{mi})$ and often cover a total area up to 100 square km (39 square mi) (Leita et al. 1996, Visscher and Seeley 1982). Each hive contains literally thousands of bees that will forage for nectar, water, pollen, and plant resins, which are all brought back into the hive. During these foraging flights, bees inadvertently contact and accumulate a wide array of pollutants, 


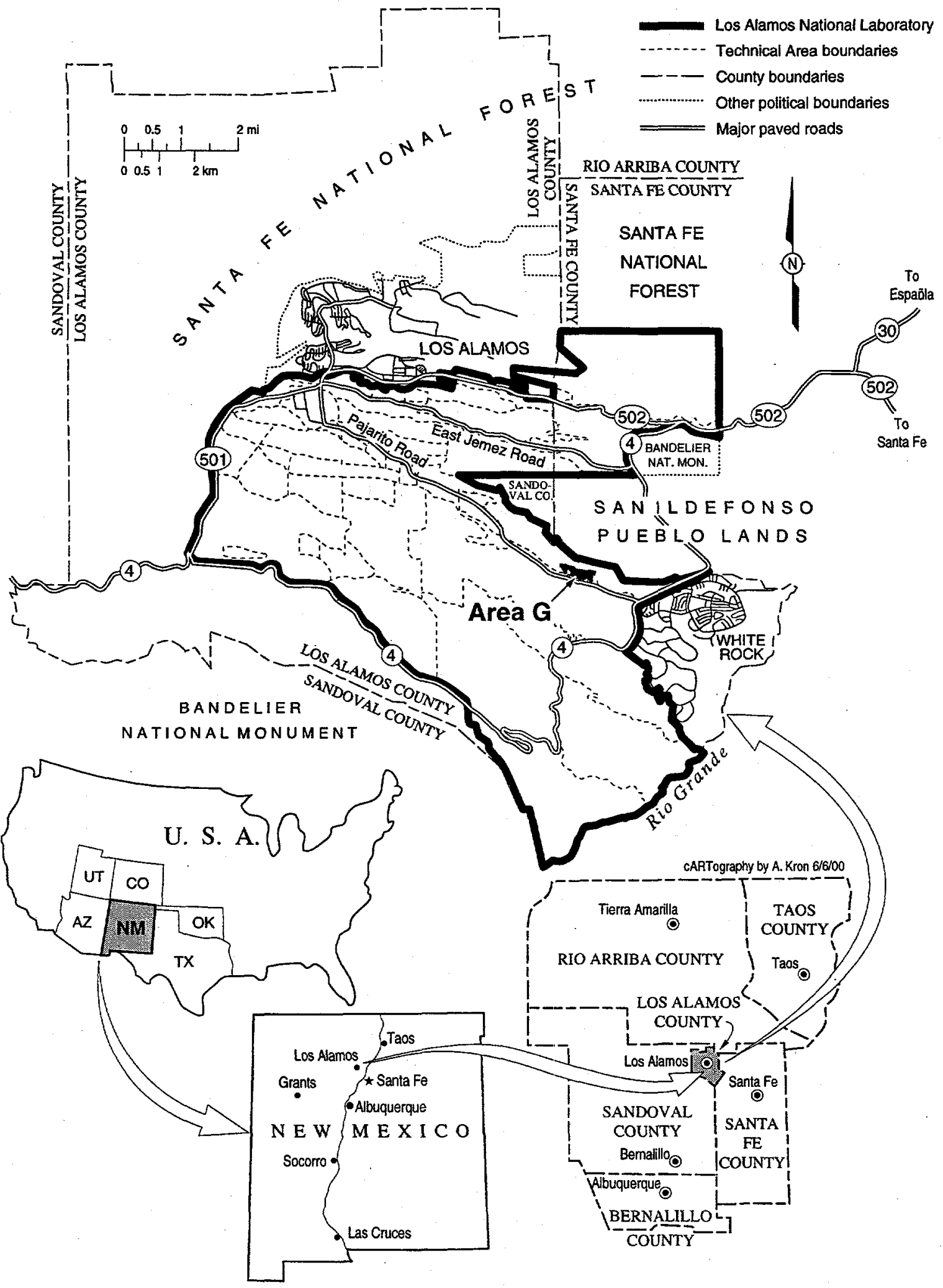

Figure 1. The location of Area $\mathrm{G}$ at Los Alamos National Laboratory. 
some of which are brought back to the colony (Bromenshenk et al. 1985). These contaminants often become incorporated into the bee tissue, the wax, the honey, or the hive itself (WallworkBarber et al. 1982).

Honey bee studies have been conducted on many different types of pollutants including fluoride (Bromenshenk et al. 1988a, Mayer et al. 1988), lead (Migula et al. 1989), zinc (Bromenshenk et al. 1988b), nickel (Balestra et al. 1992), potassium (Barbattini et al. 1991), cesium (Bettoli et al. 1987, Tonelli et al. 1990), tritium (White et al. 1983, Fresquez et al. 1997b), and plutonium (Hakonson and Bostick 1976). Honey bee sampling is an inexpensive form of monitoring, especially considering the many different sampling points the foraging bees visit. Collection of bees at one location (the hive) can provide a plethora of information from numerous points concerning the distribution and bioavailability of contaminants. Comparing the amounts of contaminants in honey bees with the known amounts of contaminants in the surrounding area could be useful for modeling the redistribution of contaminants through ecosystems. The very nature of honey bee ecology makes them an excellent living system from which to monitor the presence of contaminants.

The objective of this study was to compare various radionuclide concentrations in honey bees from Area G with honey bees collected from a background location.

\section{METHODS}

We monitored Area $G$ using beehives consisting of a standard Langstroth hive stocked with Italian honey bees (Apis mellifera ligustica). During 1997, two colonies were established on the south end of Area G near the ${ }^{3} \mathrm{H}$ shafts (Figure 2). These colonies were brought into the study site from an uncontaminated area. In addition, a control (background) site with one colony was established $10 \mathrm{~km}$ (6 mi) south of Jemez Springs, NM.

In the early fall of 1999 , bee tissue samples were collected from all of the colonies. Three separate samples (one from each colony), each containing approximately $100 \mathrm{~g}$ of bees, were collected. Each individual 100-g sample 


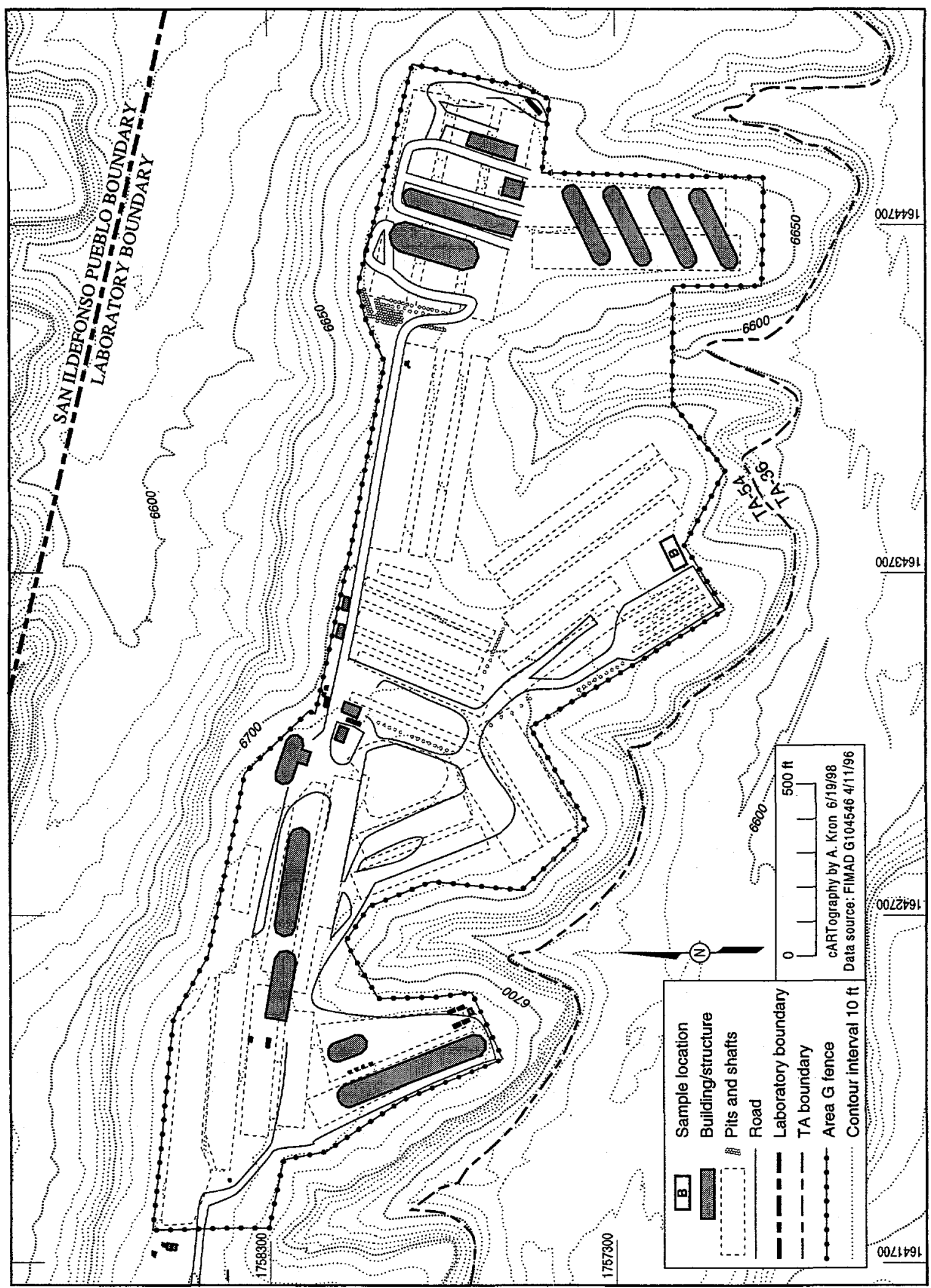

Figure 2. Site/sample location of bee hives at Area G. 
consisted of approximately 1,000 bees. Bee samples were collected using a small, rechargeable vacuum. Bees were vacuumed off frames that were removed from the honey supers, transferred to a plastic resealable bag, weighed, and double bagged into plastic resealable bags. All samples were kept in a cooler and frozen upon returning to the laboratory. With each sample collected, the vacuum collection area was thoroughly cleaned to avoid crosscontamination of samples.

All samples were analyzed by LANL's Environmental Chemistry Group for ${ }^{3} \mathrm{H},{ }^{137} \mathrm{Cs},{ }^{241} \mathrm{Am},{ }^{238} \mathrm{Pu}$, ${ }^{239,240} \mathrm{Pu},{ }^{90} \mathrm{Sr}$, and total uranium. Analytical methods have been previously described in Fresquez et al. (1997c). The bee ${ }^{3} \mathrm{H}$ samples were analyzed by liquid scintillation counting in the following manner: $5 \mathrm{ml}$ of moisture were distilled from each sample, mixed with $15 \mathrm{ml}$ of a scintillation solution, and counted on a scintillation counter for 50 minutes. The gamma-emitting radionuclide concentrations were determined using high-resolution germanium detector gamma-ray spectrometry. However, for a more accurate analysis of ${ }^{241} \mathrm{Am}$, alpha spectrometry was used. $\mathrm{Am}$ and $\mathrm{Pu}$ samples were dissolved in nitric acid, isolated by anion exchange, electroplated onto stainless steel disks, and counted using an alpha spectrometer. Total uranium was determined by kinetic phosphorescence analysis.

\section{RESULTS}

Table 1 contains a summary of the 1999 analytical results from samples collected near Area $G$ and the control site. The original analytical reports are included in the Appendix for future reference. For the purpose of this report, only concentrations that were at detectable levels-where the analytical result was higher than two times the counting uncertainty-are discussed in further detail.

In general, most radionuclides, with the exception of ${ }^{3} \mathrm{H},{ }^{90} \mathrm{Sr}$, and total uranium, were within the regional statistical reference level (RSRL). The RSRL is the upper (95\%) level background concentration (mean + two std dev) derived from the combined 1997, 1998, and 1999 control data 
(Haarmann 1997; Haarmann and Fresquez 1998, 1999). Similar to our results from 1997 and 1998, the largest concentration difference between Area G and the RSRL was seen in the ${ }^{3} \mathrm{H}$ levels. Tritium levels in the Area $G$ bees, for example, were at 146.9 and $122.0 \mathrm{pCi}$ $\mathrm{mL}^{-1}$; the control colony contained -0.10 pCi mL ${ }^{-1}$, with a RSRL of $5.47 \mathrm{pCi} \mathrm{mL}^{-1}$.
Concentrations of ${ }^{90} \mathrm{Sr}$ were higher in one Area $G$ colony than the RSRL. Additionally, concentrations of total uranium were higher than the RSRL in the other Area G colony.

\section{ACKNOWLEDGMENT}

Thanks to Rebecca J. Wechsler, for technical assistance at Area G.

Table 1. Radionuclide Analytical Results from Honey Bee Samples Collected from Colonies at Area G and a Control Site in 1999.

\begin{tabular}{llllllllll}
\hline Element & Units & Area G & G-1 & $\mathbf{A U}^{\mathrm{a}}$ & $\begin{array}{c}\text { Area G } \\
\text { G-2 }\end{array}$ & $\mathbf{A U}$ & Control & AU & RSRL \\
\hline${ }^{238} \mathbf{P u}$ & $\mathrm{pCi} / \mathrm{g}^{\mathrm{b}}$ & -0.0160 & 0.0081 & -0.0107 & 0.0122 & -0.0063 & 0.0034 & $0.0063^{\mathrm{c}}$ \\
${ }^{239,240} \mathbf{P u}$ & $\mathrm{pCi} / \mathrm{g}^{\mathrm{b}}$ & -0.0117 & 0.0106 & 0.0060 & 0.0128 & -0.0014 & 0.0025 & $0.0222^{\mathrm{c}}$ \\
${ }_{\text {total }} \mathrm{U}$ & $\mu \mathrm{g} / \mathrm{g}^{\mathrm{b}}$ & 0.46 & 0.05 & 0.39 & 0.04 & 0.31 & 0.03 & $0.41^{\mathrm{c}}$ \\
${ }^{\mathbf{1 3 7}} \mathbf{C s}$ & $\mathrm{pCi} / \mathrm{g}^{\mathrm{b}}$ & -0.38 & 6.39 & 0.00 & 6.00 & -1.01 & 3.98 & $0.101^{\mathrm{c}}$ \\
${ }^{241} \mathbf{A m}$ & $\mathrm{pCi} / \mathrm{g}^{\mathrm{b}}$ & -0.0048 & 0.0032 & -0.0118 & 0.0134 & -0.0064 & 0.0052 & $0.0304^{\mathrm{c}}$ \\
${ }^{90} \mathrm{Sr}$ & $\mathrm{pCi} / \mathrm{g}^{\mathrm{b}}$ & 0.61 & 1.06 & 4.22 & 1.22 & 1.63 & 0.69 & $3.01^{\mathrm{d}}$ \\
${ }^{3} \mathbf{H}$ & $\mathrm{pCi} / \mathrm{mL}^{\mathrm{e}}$ & 146.90 & 5.40 & 122.00 & 4.70 & -0.10 & 0.61 & $5.47^{\mathrm{c}}$ \\
\hline
\end{tabular}

\footnotetext{
${ }^{2}$ Analytical Uncertainty; values are the uncertainty in the analytical results at the $65 \%$ confidence level (one sigma).

${ }^{\mathrm{b}}$ Units are in $\mathrm{g}$ per ash.

${ }^{\mathrm{c}}$ Regional Statistical Reference Level; the upper (95\%) level background concentration (mean + two sigma) from 1997, 1998, and 1999 control data.

${ }^{d}$ Regional Statistical Reference Level; the upper (95\%) level background concentration (mean + two sigma) from present control data.

${ }^{e}$ Units are in mL tissue moisture.
} 


\section{REFERENCES}

Balestra, V., G. Celli, and C. Porrini, "Bees, Honey, Larvae and Pollen in Biomonitoring of Atmospheric Pollution," Aerobiologia 8:122-126 (1992).

Barbattini, R., F. Frilli, M. Iob, C. Giovani, and R. Padovani, "Transfer of Cesium and Potassium by the 'Apiarian Chain' in Some Areas of Friuli [NE Italy]," Apicoltura 7:8587 (1991).

Bettoli, M.G., A.G. Sabatini, M.A. Vecchi, "Honey Produced in Italy since the Chernobyl Incident," Apitalia 14(10):5-7 (1987).

Bromenshenk, J.J., "Site-specific and Regional Monitoring with Honey Bees: Case Study Comparisons," In Proc. of Int. Symp. on Ecological Indicators, Volume 39, Fort Lauderdale, FL. 16-19 Oct. 1990, Elsevier Sci. Publ. London, UK (1992).

Bromenshenk, J.J., S.R. Carlson, J.C. Simpson, J.M. Thomas, "Pollution Monitoring of Puget Sound with Honey Bees," Science 227:800-801 (1985).

Bromenshenk, J.J., R.C. Cronn, J.J. Nugent, and G.J. Olbu, "Biomonitoring for the Idaho National Engineering Laboratory: Evaluation of Fluoride in Honey Bees," American Bee Journal 128(12):799-800 (1988a).

Bromenshenk, J.J., J.L. Gudatis, R.C. Cronn, J.J. Nugent, and G.J. Olbu, "Uptake and Impact of Heavy Metals to Honey Bees," American Bee Journal 128(12):800-801 (1988b).

Fresquez, P.R., D.R. Armstrong, and L.H. Pratt, "Radionuclides in Bees and Honey Within and Around Los Alamos National Laboratory," Journal of Environmental Science and Health, A32(5) 1309-1323 (1997a). 
Fresquez, P.R., E.L. Vold, and L. Naranjo, Jr., "Radionuclide Concentrations in Soils and Vegetation at Radioactive-Waste Disposal Area G during 1996 Growing Season," Los Alamos National Laboratory report LA-13332-PR (1997b).

Fresquez, P.R., D.R. Armstrong, and L.H. Pratt, "Tritium Concentrations in Bees and Honey at Los Alamos National Laboratory: 1979-1996," Los Alamos National Laboratory report LA-13202-MS (1997c).

Haarmann, T.K., "Honey Bees as Indicators of Radionuclide Contamination: Exploring Colony Variability and Temporal Contaminant Accumulation," Journal of Apicultural Research 36(2):77-87 (1997).

Haarmann, T.K., and P.R. Fresquez, "Radionuclide Concentrations in Honey Bees from Area G at TA-54 during 1997," Los Alamos National Laboratory report LA-13480-PR (1998).

Haarmann, T.K., and P.R. Fresquez, "Radionuclide Concentrations in Honey Bees from Area G at TA-54 during 1998," Los Alamos National Laboratory report LA-13613-PR (1999).

Hakonson, T.E., and K.V. Bostick, "The Availability of Environmental Radioactivity to Honey Bee Colonies at Los Alamos," Journal of Environmental Quality 5(3):307-309 (1976).

Leita, L., G. Muhlbachova, S. Cesco, R. Barbattini, C. Mondini, "Investigation of the Use of Honey Bees and Honey Bee Products to Assess Heavy Metals Contamination," Environmental Monitoring and Assessments 43:1-9 (1996). 
Mayer, D.G., I.D. Lunden, L.H. Weinstein, "Evaluation of Fluoride Levels and Effects on Honey Bees (Apis mellifera L.)," Fluoride 21:113-120 (1988).

Migula, P., K. Binkowska, A. Kafel, M. Nakonieczy, "Heavy Metal Contents and Adenylate Energy Charge in Insects from Industrialized Region as Indices of Environmental Stress," Proceedings of the 5th International Conference, Bioindicatores Deteriorisationis Regionis, II. Ceske Budejovice, Czechoslovakia: Institute of Landscape Ecology (1989).

Tonelli, D., E. Gattavecchia, S. Ghini, C. Porrini, G. Celli, A.M. Mercuri, "Honey Bees and their Products as Indicators of Environmental Radioactive Pollution," Journal of Radioanalytical and Nuclear Chemistry 141(2):427-436 (1990).

Visscher, P.K., and T.D. Seeley, "Foraging Strategy of Honey Bee Colonies in a Temperate Deciduous Forest," Ecology 63:1790-801 (1982).

Wallwork-Barber, M.K., R.W. Ferenbaugh, and E.S. Gladney, "The Use of Honey Bees as Monitors of Environmental Pollution," American Bee Journal 122(11):770-772 (1982).

White, G.C., T.E. Hakonson, and K.V. Bostick, "Fitting a Model of Tritium Uptake by Honey Bees to Data," Ecological Modeling 18(3/4):241-251 (1983). 


\section{APPENDIX}

CST ANALYTICAL REPORTS OF RADIONUCLIDES IN BEES 
Los Alamos

NATIONAL LABORATORY

Memorandom

Chemical Science and Technology

Responsible Chemistrv for America

CST-9/Analytical Chemistry Sciences

Los Alamos. New Mexico 87545

This is a Case Narrative for the following:
To/MS: Phil Fresquez ESH-20/M887

From/MS: Claudine Armenta/K484

Phone'F.4.X: 5-7358/5-5982

Symbol: CST-9/00

Date: March 28. 2000

\section{Submissinn In \\ Analysis}

\section{: 100040.337}

: Am analysis on Biological Samples

\section{Introduction}

On September 20, 1999 four biological samples were delivered to the CST-9 radiochemistry section for the requested analysis.

\section{Analytical Results/Methodology}

The analytical results are presented as indicated by the terms on the Analytical Service Agreement. Each set of data will include sample identification information, the analytical results, and other information as required by the customer.

The analys is requested is: Americium-241 in Environmental Matrices, (Water, Air Filter \& Biological Samples) - Alpha Spectroscopy. The specific procedure can be found either on line @ http://est.lanl.gov/docs, or in hardcopy form within the document entitled LA-10300-M, Vol. III, Method ANC. 327-R.0.

\section{Quality Control}

The appropriate quality control samples were analyzed with the samples.

\section{Comments}

Four samples were analyzed for Americium-241. These samples are spiked with Americium-243.

All Quality Control parameters are within appropriate limits and as such meet CST-9's quality assurance program objectives. This data was added to batch B-16-00Am with other submissions (100040524, 100040881 and 100040882 ). The Replicate information is with submission 100040882.

I verify, to the best of my knowledge that the listed results are both complete and technically correct, with the exception of the item(s) detailed above.

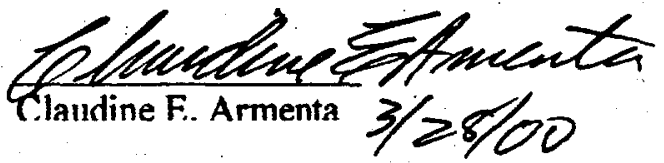


Method: AM RAS ENV Method Area: EH-ALPHA

Submission Id :

100040337

\begin{tabular}{|c|c|c|c|c|c|}
\hline Requester Name: & TIM HAARMANN & Customer Cost Code: & FT00C34A05FF400000 & Due Date: & 22-NOV-99 \\
\hline Requester Group: & ESH-20 & Logged Date: & 20-SEP-1999 & Screening Data: & NO SCREENING DATA REQUIRED \\
\hline Mall Stop: & M887 & Study: & ESH20 BIOLOGICALS & & \\
\hline Requester Phone: & $667-081.5$ & & & logged by: & APODACA \\
\hline Requester Fax \#: & $667-07.31$ & Analytical Service Agr & & & \\
\hline
\end{tabular}

\section{CUSTOMER SAMPLES}

\begin{tabular}{|c|c|c|c|}
\hline Sample Id & Task Id & Customer Id & Component \\
\hline 200109136 & 300235206 & G-1 & $\begin{array}{l}\text { Am-241 } \\
\text { Am-241 DL } \\
\text { Am-243T Recovery } \\
\text { Analysis Date } \\
\text { Instrument } \\
\text { Problem Code } \\
\text { Count Time } \\
\text { Efficiency }\end{array}$ \\
\hline 200109137 & 300235211 & G.2 & $\begin{array}{l}\text { Am-241 } \\
\text { Am-241 DI. } \\
\text { Am-243T Recovery } \\
\text { Analysis Date } \\
\text { Instrument } \\
\text { Problem Code } \\
\text { Count Time } \\
\text { Efficiency }\end{array}$ \\
\hline 2001091.38 & 300235216 & $C \cdot 1$ & $\begin{array}{l}\text { Am-241 } \\
\text { Am-241 DL }\end{array}$ \\
\hline
\end{tabular}

Result Value
-0.0048
0.0196
99.40
$12-$ MAR-2000
32 ALPHA
OK
3000.00
31.62
-0.0118
0.0114
101.78
$12-M A R-2000$
32 ALPHA
OK
3000.00
28.76
-0.0064
0.0082

\begin{tabular}{|c|c|}
\hline Uncertainty & Units \\
\hline \multirow[t]{8}{*}{0.0032} & $\mathrm{pCi} / \mathrm{g}$ \\
\hline & $\mathrm{pCi} / \mathrm{g}$ \\
\hline & $\%$ \\
\hline & DD-MON-YYYY \\
\hline & NONE \\
\hline & NONE \\
\hline & $\min$ \\
\hline & $\%$ \\
\hline \multirow[t]{8}{*}{0.0134} & $\mathrm{pCi} / \mathrm{g}$ \\
\hline & $\mathrm{pC} \mathrm{i} / \mathrm{g}$ \\
\hline & $\%$ \\
\hline & DD-MON-YYYY \\
\hline & NONE \\
\hline & NONE \\
\hline & $\min$ \\
\hline & $\%$ \\
\hline \multirow[t]{2}{*}{0.0052} & $\mathrm{pCi} / \mathrm{g}$ \\
\hline & $\mathrm{pCi} / \mathrm{g}$ \\
\hline
\end{tabular}

Qualifier 

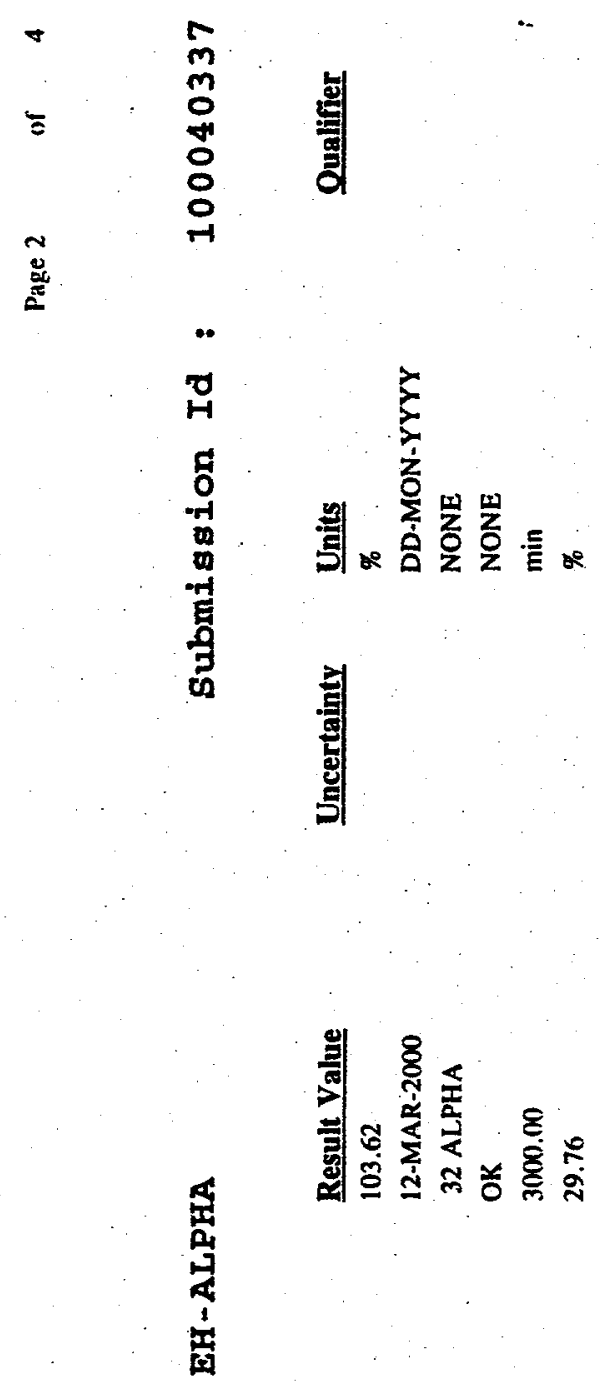

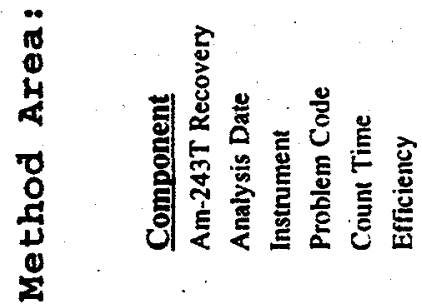

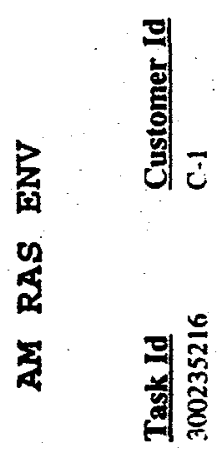

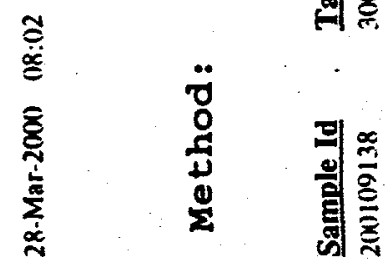


Method: AM RAS ENV Method Area: EH-ALPHA

Submisaion Id:

100040337

************ CST QUALITY ASSURANCE REPORT **********

BLIND QC

Customer Id

200109140

\section{Task Id} 300235219

Component

Am-241

Result

Value

Uncertainty

0.1221

$\frac{\text { Units }}{\mathrm{pCi} / \mathrm{g}}$

Result

Value

Uncertainty

0.0006

Units

$\mathrm{pCi} / \mathrm{L}$

QC
Value

$\frac{\text { Value }}{0.0023}$

QC

Uncertaint

0.00023

QC

units pCi/L

QC

Evaluation IN CONTROL

\section{METHOD BLANK}

QC

Value Uncertainty units Evaluation 
Method:
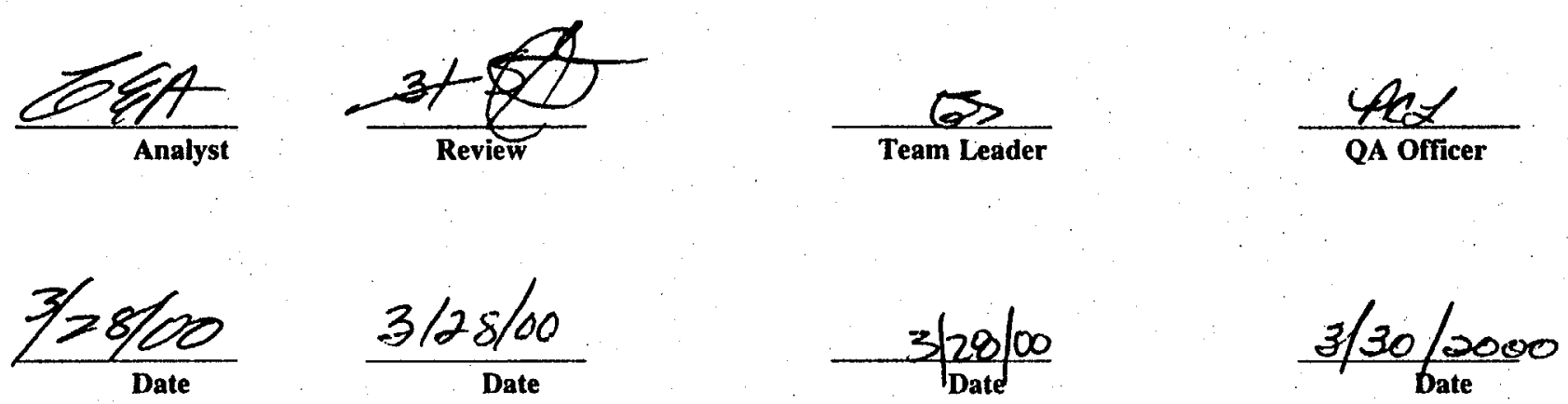

The control status of the preceeding data was evaluated using the standard statistical criteria set forth in Quality Assurance for Health and Environmental Chemistry: 1992, LA-12790-MS, Vol I, pp. 19-29.

"The reported uncertainties are at the 1 sigma confidence level unless otherwise stated." 
Los Alamos

NATIONAL LABORATORY

Memorandum

Chemical Science and Technology

Responsible Chemistrv for America

CST-9/Analytical Chemistry Sciences

Los Alamos. New Mexico 87545

This is a Case Narrative for the following:
To/MS: Tim Haarmann ESH-20M887

From/MS: Claudine Armenta/K484

Phone'F.4.Y: 5-7358/5-5982

Sumbol: CST-9/00

Date: March 25. 2000

\section{Suhmission ID $\quad: 100040337$ \\ Analysis $\quad$ : Pu analysis on Biological Samples}

\section{Intmduction}

On September 20, 1999 three biological samples were delivered to the CST-9 radiochemistry section for the requested analysis.

\section{Analytical Results/Methodology}

The analytical results are presented as indicated by the terms on the Analytical Service Agreement. Each set of data will include sample identification information, the analytical results, and other information as required by the customer.

The analysis requested is: Actinides In Environmental Matrices, (Biological A\& Filters) - Alpha Spectroscopy. The specific procedure can be found either on line @ http://cst.lanl.gov/docs, or in hardcopy form within the document entitled LA-10300-M, Vol. III, Method ANC 372 R.0.

\section{Quality Control}

The appropriate quality control samples were analyzed with the samples.

\section{Comments}

Three samples were analyzed for Plutonium-238 and Plutonium-239. These samples are spiked with Plutonium-242.

All Quality Control parameters are within appropriate limits and as such meet CST-9's quality assurance program objectives. This set was put into a batch with other submissions 100040524,100040881 and 100040882 batch name is $\mathrm{B}-15-00 \mathrm{Pu}$. The replicate information is with submission 100040882 .

I verify, to the best of my knowledge that the listed results are both complete and technically correct, with the exception of the item(s) detailed above.

\footnotetext{
Claudine F. Armenta 
Requester Name:

Requester Group:

Mail Stop:

Requester Phone:

Requester Fax \#:

TIM HAARMANN
ESH-20
M887
$667-0815$
$667-0731$

\section{Customer Cost Code:}

Logged Date:

Study:

Analytical Service Agreement \#:
FT00C34A0SFF400000

20-SEP-1999

ESH20 BIOLOGICALS

\section{CUSTOMER SAMPLES}

\begin{tabular}{|c|c|c|c|c|c|c|}
\hline Sample Id & Task Id & Customer Id & Component & Result Value & Uncertainty & Units \\
\hline 200109136 & 300235203 & G-1 & $\mathrm{Pu}-238$ & -0.0160 & 0.0081 & $\mathrm{pCi} / \mathrm{g}$ \\
\hline & & & Pu-238 DL & 0.0342 & & $\mathrm{pCi} / \mathrm{g}$ \\
\hline & & & Pu-239 & -0.0117 & 0.0106 & $\mathrm{pCi} / \mathrm{g}$ \\
\hline & & & Pu-239 DL & 0.0442 & & $\mathrm{pCi} / \mathrm{g}$ \\
\hline & & & Pu-242T Recovery & 98.13 & & $\%$ \\
\hline & & & Analysis Date & 20-MAR-2000 & & DD-MON-YYYY \\
\hline & & & Instrument & 96 ALPHA & & NONE \\
\hline & . & & Problem Code & OK & & NONE \\
\hline & & & Count Time & 3000.00 & & $\min$ \\
\hline & & & Efficiency & 24.48 & & $\%$ \\
\hline \multirow[t]{8}{*}{200109137} & 300235208 & G-2 & Pu-238 & -0.0107 & 0.0122 & $\mathrm{pCi} / \mathrm{g}$ \\
\hline & & & Pu-238 DL & 0.0542 & & $\mathrm{pCi} / \mathrm{g}$ \\
\hline & & & Pu-239 & 0.0060 & 0.0128 & $\mathrm{pCi} / \mathrm{g}$ \\
\hline & & & $\mathrm{Pu} \cdot 239 \mathrm{DL}$ & $0.05(19$ & & $\mathrm{pCi} / \mathrm{g}$ \\
\hline & & & Pu-242T Recovery & 94.15 & & $\%$ \\
\hline & & & Analysis Date & 20-MAR-2000 & & DD-MON-YYYY \\
\hline & & & Instrument & 96 ALPHA & & NONE \\
\hline & & & Problem Code & OK & & NONE \\
\hline
\end{tabular}

.

Qualifier 
Method:

Sample Id Task Id

$200109137 \quad 300235208$

\section{Customer Id}

G-2

Component

Count Time

Efficiency

Pu-238

Pu-238 DI,

Pu-239

Pu-239 DL

Pu-242T Recovery

Analysis Date

Instrument

Problem Code

Count Time

Efficiency

\begin{tabular}{l} 
Result Value \\
\hline 3000.00 \\
24.24 \\
-0.0063 \\
$0.0160)$ \\
-0.0014 \\
0.0082 \\
94.82 \\
$20-$ MAR-2000 \\
96 ALPHA \\
OK \\
3000.00 \\
26.51 \\
\hline
\end{tabular}

Uncertainty

$\frac{\text { Units }}{\min }$

$\%$

0.0034

0.0025

$\mathrm{pCi} / \mathrm{B}$

$\mathrm{pCi} / \mathrm{g}$

$\mathrm{pCi} / \mathrm{g}$

$\mathrm{pCi} / \mathrm{g}$

$\%$

DD-MON-YYYY

NONE

NONE

min

Qualifier 
0
0
0
0
0
0
0
0
0
0
0
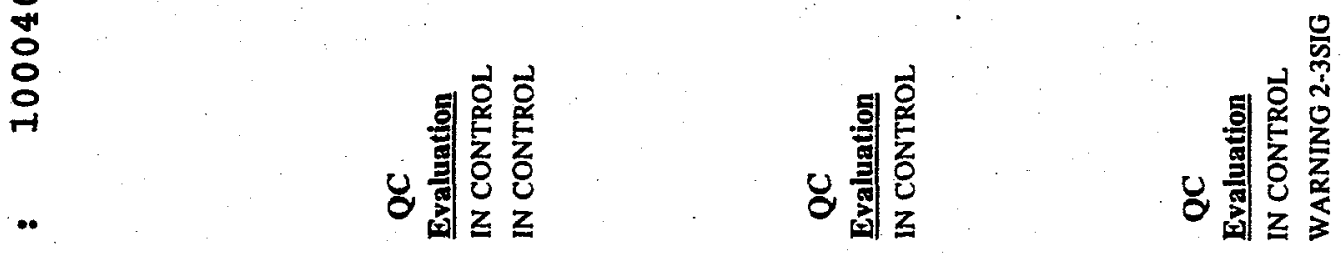

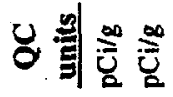

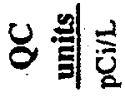

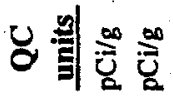

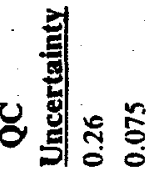

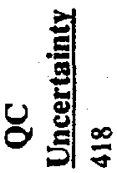

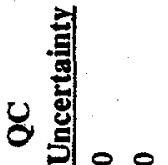

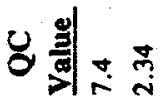

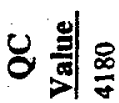

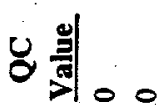

횧ำ

힣함

ㅎํㄱำ

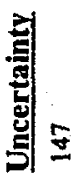

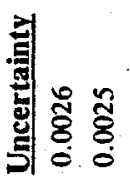

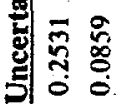

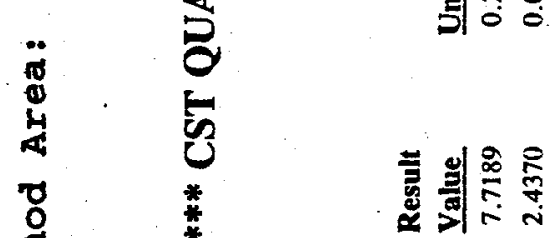

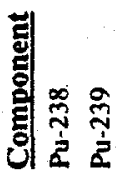

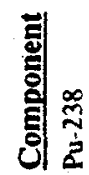

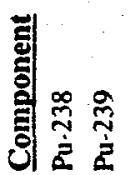

品

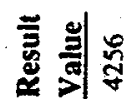

裏讏爱

窟

品

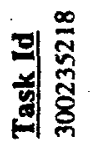

믜 冚
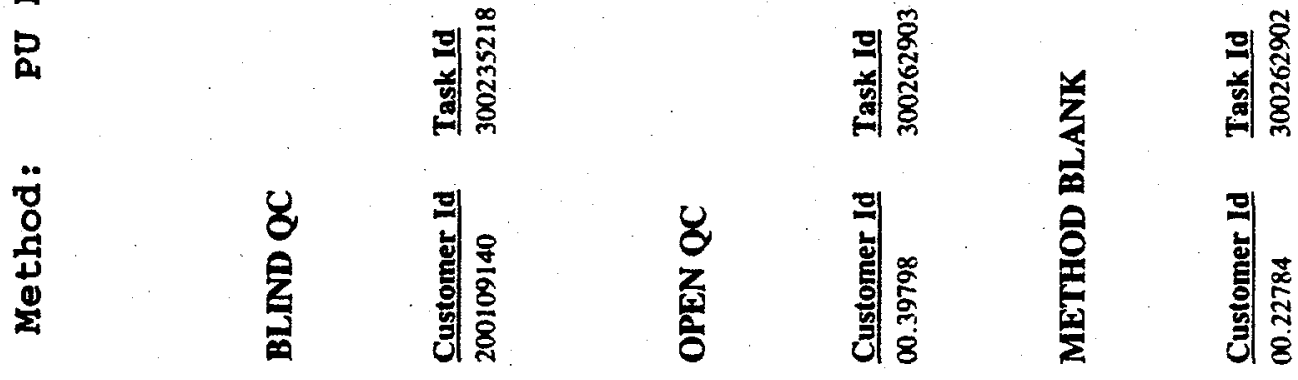

8 

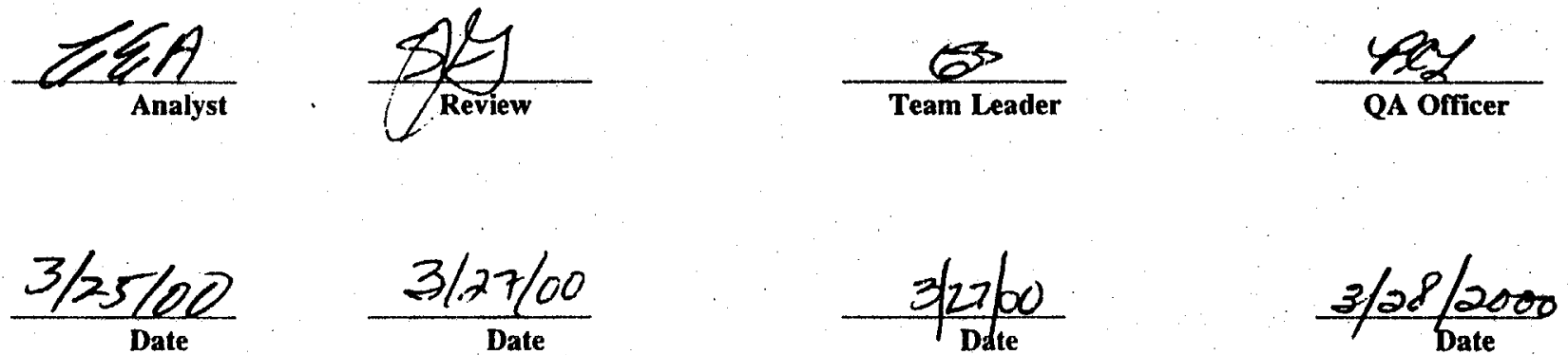

The control status of the preceeding data was evaluated using the standard statistical criteria set forth in Quality Assurance for Health and Environmental Chemistry: 1992, LA-12790-MS, Vol I, pp. 19-29.

"The reported uncertainties are at the 1 sigma confidence level unless otherwise stated." 
Los Alamos

NATIONAL LABORATORY

Memorandum

Chemical Science and Technology

Responsible Chemistry for America CST-9/Analytical Chemistry and Science

Los Alamos, New Mexico 87545

This is a Case Narrative for the following:

Submission ID: 100040337

Analysis: Sr-90 in ash

\section{Introduction}

In September 1999, a set of samples was delivered to the CST-9 radiochemistry section for the requested analysis.

\section{Analytical Results/Methodology}

The analytical results are presented as indicated by the terms on the Analytical Service Agreement. Each set of data will include sample identification information, the analytical results, and other information as required by the customer.

The analysis requested is: Strontium In Water - Liquid Scintillation Counting. The specific procedure can be found either on line @ http://cst.lanl.gov/docs, or in hardcopy form within the document entitled LA-10300-M, Vol. III, Method ANC367, R.1.

\section{Quality Control}

The appropriate quality control samples were analyzed with the samples.

\section{Comments}

This case narrative was generated to document the circumstances that were involved with the development if this data package. All QA perimeters were in control. There are also no replicate analyses due to insufficient sample.

I verify, to the best of my knowledge that the listed results are both complete and technically correct, with the exception of the item(s) detailed above.

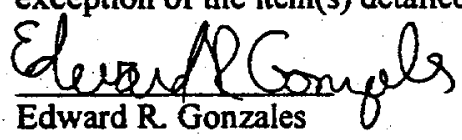




\section{Nothod:}

SR-90 is ENV
EH - ALPHA

Submis B 1 on I d

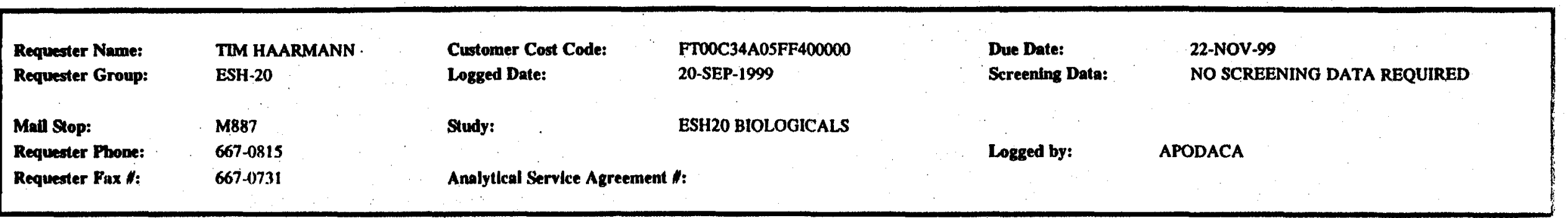

\section{CUSTOMER SAMPLES}

$\begin{array}{llll}\text { Sample Id } & \text { Task Id } & \text { Customer Id } & \begin{array}{l}\text { Component } \\ \text { Sr-90 } \\ \text { Sr-90 MDA }\end{array} \\ & \text { G-1 } & \begin{array}{l}\text { Analysis Date } \\ \text { Comments } \\ \text { Sr-90 }\end{array} \\ 200109136205 & 300235210 & \text { G-2 } & \begin{array}{l}\text { Sr-90 MDA } \\ \text { Analysis Date } \\ \text { Comments }\end{array} \\ 200109138 & 300235215 & \text { C-1 } & \begin{array}{l}\text { Sr-90 } \\ \text { Sr-90 MDA } \\ \end{array} \\ & & & \text { Analysis Date } \\ & & \text { Comments }\end{array}$

Result Value
0.61
2.38
$22-$ FEB-2000
NA
4.22
2.28
$22-$ FEB-2000
NA
1.63
1.38
$22-$ FEB-2000
NA

\begin{tabular}{|c|c|}
\hline Uncertainty & Units \\
\hline \multirow[t]{4}{*}{1.06} & $\mathrm{pCi} / \mathrm{g}$ \\
\hline & $\mathrm{pCi} / \mathrm{g}$ \\
\hline & DD-MON-YYYY \\
\hline & NONE \\
\hline \multirow[t]{4}{*}{1.22} & $\mathrm{pCi} / \mathrm{g}$ \\
\hline & $\mathrm{pCi} / \mathrm{g}$ \\
\hline & DD-MON-YYYY \\
\hline & NONE \\
\hline \multirow[t]{4}{*}{0.69} & $\mathrm{pCi} / \mathrm{g}$ \\
\hline & $\mathrm{pCi} / \mathrm{g}$ \\
\hline & DD-MON-YYYY \\
\hline & NONE \\
\hline
\end{tabular}

Qualifier 
$\therefore \quad \frac{\pi}{3}$

8

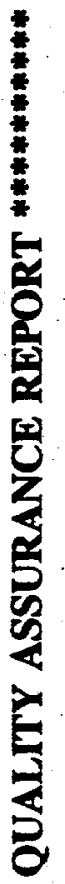

g

$E$

on

0

a

$\overline{5}$

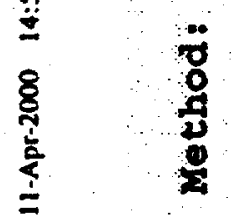

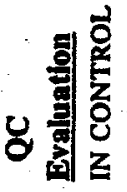

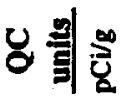

영 형영

일 임

볌뉼

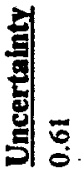

$\underset{n}{n}$

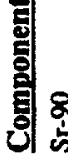

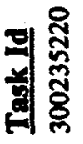

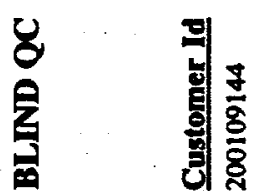

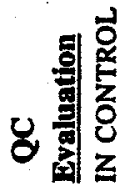

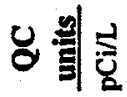

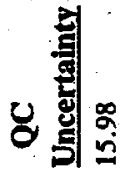

웡영

8 읳

힙홍

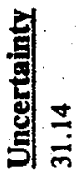

衰 웠

횧물

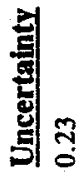

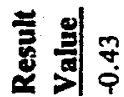

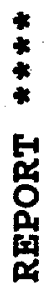

岂

*

영영

영

쿠유융

$\frac{8}{8}$
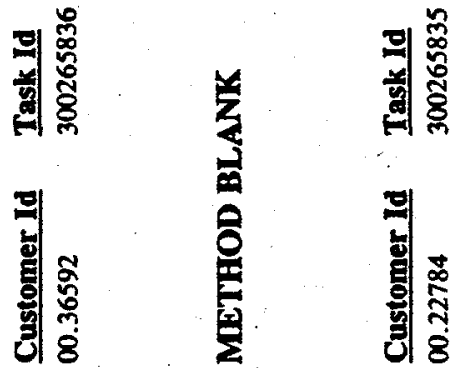
Method: SR-90 LS ENV
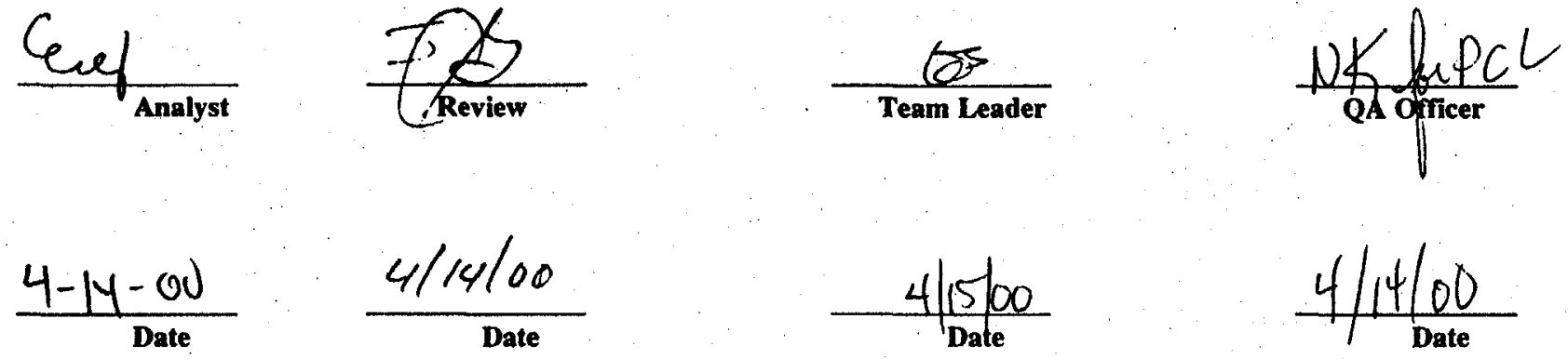

The control status of the preceeding data was evaluated using the standard statistical criteria set forth in Quality Assurance for Health and Environmental Chemistry 1992, LA-12790-MS, Vol I, pp. 19-29.

"The reported uncertainties are at the 1 sigma confidence level unless otherwise stated." 
Los Alamos

NATIONAL LABORATORY

Memorandum

Chemical Science and Technology

Responsible Chemistry for America

CST-9/Inorganic Trace Analysis

Los Alamos, New Mexico 87545
To/MS: Phil Fresquez / MS M887

From/MS: Anthony Sanchez/MSK484

Phone/FAX: 7-5998/5-5982

Symbol: CST-9/99.

Date: October 14,1999

This is a Case Narrative for the following:

Submission ID: 100040342

Analysis: Tritium Analysis in Water

\section{Introduction}

On September 20,1999, a set of water samples was delivered to the CST-9 radiochemistry section for the requested analysis.

\section{Analytical Results/Methodology}

The analytical results are presented.as indicated by the terms on the Analytical Service Agreement. Each set of data will include sample identification information, the analytical results, and other information as required by the customer.

The analysis requested is Tritium in Environmental Matrices - Distillation and Liquid Scintillation Counting. The specific procedure can be found either on line @ http://est.lanl.gov/docs, or in hardcopy form within the document entitled LA-10300-M, Vol. III, Method ANC335, R.1.

\section{Quality Control}

The appropriate quality control samples were analyzed with the submitted samples.

\section{Comments}

This case narrative was generated to document the circumstances that were involved with the development of this data package. This submission was batched with other submission's for QA and QC. I verify, to the best of my knowledge, that the listed results are both complete and technically correct.

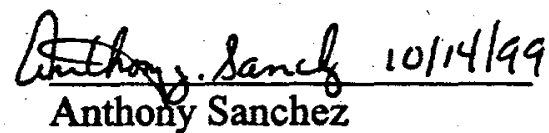


Analytical

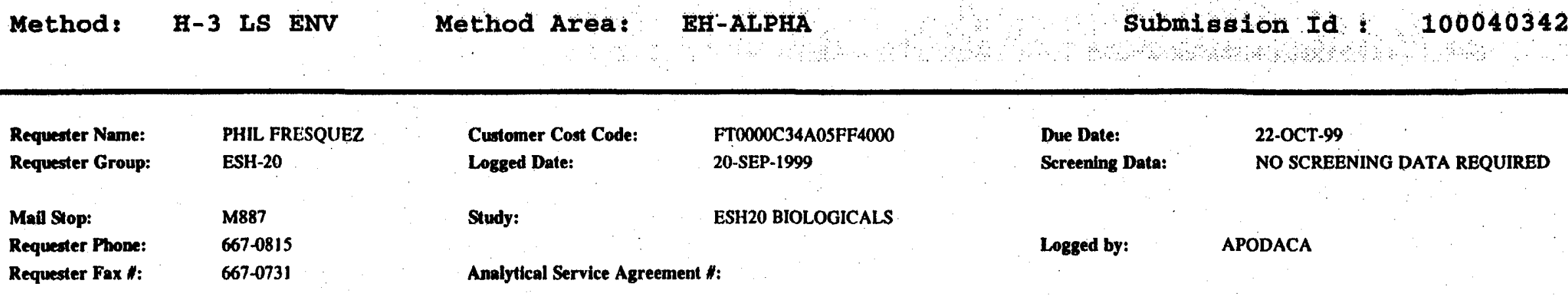

\section{CUSTOMER SAMPLES}

\begin{tabular}{|c|c|c|c|c|c|c|c|}
\hline Sample Id & Task Id & Customer Id & Component & Result Value & Uncertainty & Units & Oualinier \\
\hline \multirow[t]{2}{*}{200109152} & 300235228 & G-1 & H-3 & 146900 & 5400 & $\mathrm{pCi} / \mathrm{L}$ & \\
\hline & & & H-3 MDA & 400 & & $\mathrm{pCi} / \mathrm{L}$ & \\
\hline \multirow[t]{2}{*}{200109153} & 300235229 & G-2 & H-3 & 122000 & 4700 & $\mathrm{pCi} / \mathrm{L}$ & \\
\hline & & & H-3 MDA & 400 & & $\mathrm{pCi} / \mathrm{L}$ & \\
\hline \multirow[t]{2}{*}{200109154} & 300235230 & $C-1$ & H-3 & -100 & 610 & $\mathrm{pCi} / \mathrm{L}$ & \\
\hline & & & H-3 MDA & 440 & & $\mathrm{pCi} / \mathrm{L}$ & \\
\hline
\end{tabular}


Method: H-3 LS ENV

Method Areat: EH-ATPRA

submigsion Ia

100040342

************ CST QUALITY ASSURANCE REPORT ***********

BLIND QC

$\frac{\text { Customer Id }}{200109155} \frac{\text { Task Id }}{300235231} \quad \frac{\text { Component }}{\text { H-3 }}$

Result

Value Uncertainty Units

H-3 14500

1400

QC

Value Uncertainty units Evaluation

$\frac{16130}{600} \quad \frac{\mathrm{pCi} / \mathrm{L}}{\text { IN CONTROL }}$ 

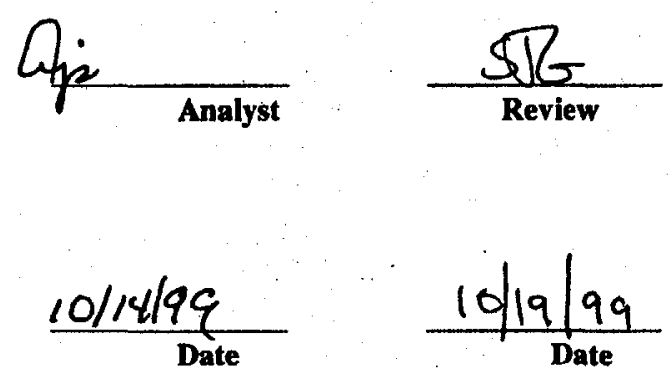

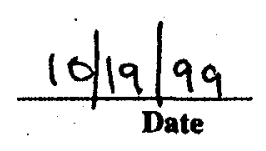

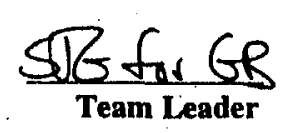

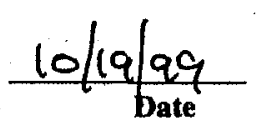

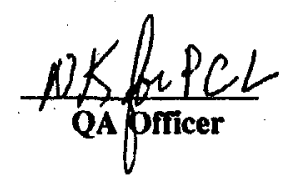

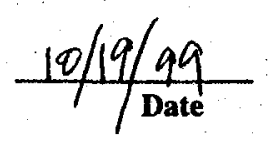

The control status of the preceeding data was evaluated using the standard statistical criteria set forth in Quality Assurance for Health and Environmental Chemistry: 1992, LA-12790-MS, Vol I, pp. 19-29.

"The reported uncertainties are at the 1 sigma confidence level unless otherwise stated." 
Los Alamos

NATIONAL LABORATORY

Memorandum

Chemical Science and Technology

Responsible Chemistry for America

CST-9/Inorganic Trace Analysis

Los Alamos, New Mexico 87545
To/MS: Phil Fresquez/ MS M887

From/MS: S. R. Garcia/ MS K484

Phone/FAX: 5-0270/5-5982

Symbol: CST2000-PRF-5

Date: February 16, 2000

This is a Case Narrative for the following:

Submission ID

$: 1000400337$

Analysis

: CS-137 ASSAY OF ASHED BEES.

\section{Introduction}

On September 20,1999 a set of ashed bee samples were delivered to the CST-9 radiochemistry section for the ${ }^{137} \mathrm{Cs}$ analysis.

\section{Analytical Results/Methodology}

The analytical results are presented as indicated by the terms on the Analytical Service Agreement. Each set of data will include sample identification information, the analytical results, and other information as required by the customer.

The analysis requested is: Gamma-Ray-Emitting Nuclides in Environmental Matrices - Gamma Spectroscopy, an Instrumental Method. The specific procedure can be found on line @ http://cst.lanl.gov/docs, Method ANC328, R.0.

\section{Quality Control}

The appropriate quality control samples were analyzed with the samples.

IV. Comments

This case narrative was generated to document the circumstances that were involved with the development if this data package.

The ashed bee samples were picked up at Cage 7, Bldg. 1, TA-59.

All Laboratory Control Samples and blind QC are within CST-9's statistical acceptance criteria. No replicate samples were available for these samples.

This submission was batched with 100041459 for QA/QC purposes.

Please feel free to call or email me if you have any questions concerning this submission.

I verify, to the best of my knowledge, that the listed results are both complete and technically correct, with the exception of the item(s) detailed above.

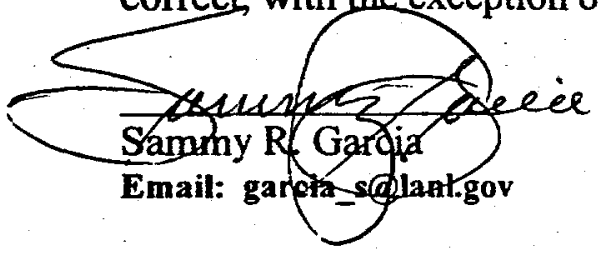




\section{Method:}

GENERIC GAMAA

Method Area:

BHA-GAMMA

Submisston Id

10.0040337

\begin{tabular}{|c|c|c|c|c|c|}
\hline Requester Name: & PHIL FRESQUEZ & Customer Cost Code: & FT00C34A05FF400000 & Due Date: & 22-NOV-99 \\
\hline Requester Group: & ESH-20 & Logged Date: & 20-SEP-1999 & Screening Data: & NO SCREENINO DATA REQUIRED \\
\hline Mail Stop: & M887 & Study: & ESH20 BIOLOGICALS & & \\
\hline Requester Phone: & $667-0815$ & & & Lorged by: & APODACA \\
\hline Requester Fax \#: & $667-0731$ & Analytical Service Agr & & & \\
\hline
\end{tabular}

CUSTOMER SAMPLES

$\begin{array}{llll}\text { Sample Id } & \text { Task Id } & \text { Customer Id } & \begin{array}{l}\text { Component } \\ \text { CS-137 } \\ \text { CS-137 MDA }\end{array} \\ 200109136 & 300235207 & \text { G.1 } & \begin{array}{l}\text { CS-137 } \\ \text { CS-137 MDA }\end{array} \\ 200109137 & 300235212 & \text { G.2 } & \begin{array}{l}\text { CS-137 } \\ \text { CS-137 MDA }\end{array}\end{array}$

Result Value
-0.38
3.20
0.000
3.00
-1.01
1.99

\begin{tabular}{ll} 
Uncertainty & Units \\
\hline 6.39 & $\mathrm{pCi} / \mathrm{g}$ \\
& $\mathrm{pCi} / \mathrm{g}$ \\
& $\mathrm{pCi} / \mathrm{g}$ \\
& $\mathrm{pCi} / \mathrm{g}$ \\
& $\mathrm{pCi} / \mathrm{g}$ \\
& $\mathrm{pCi} / \mathrm{g}$
\end{tabular}

Qualifier 


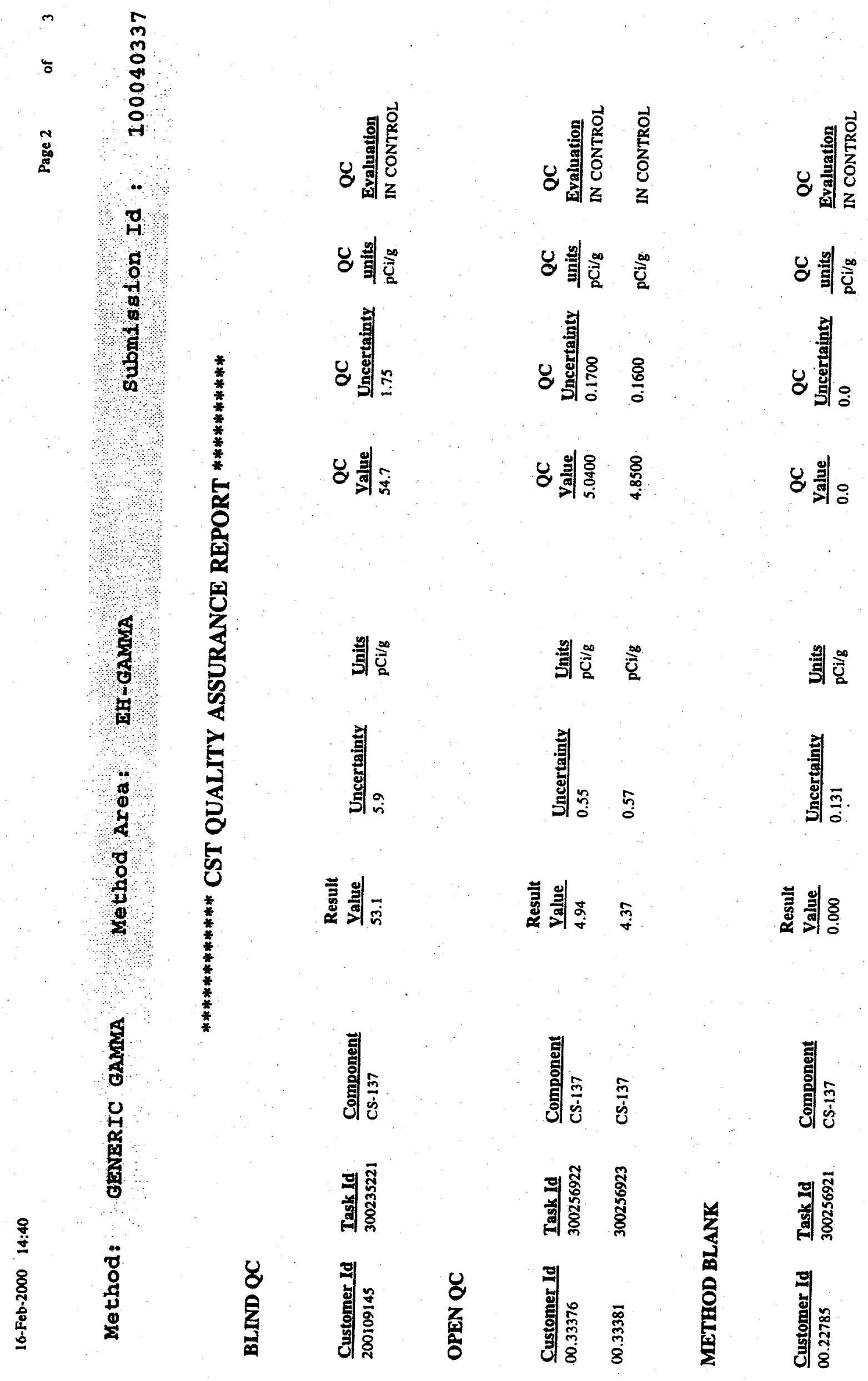



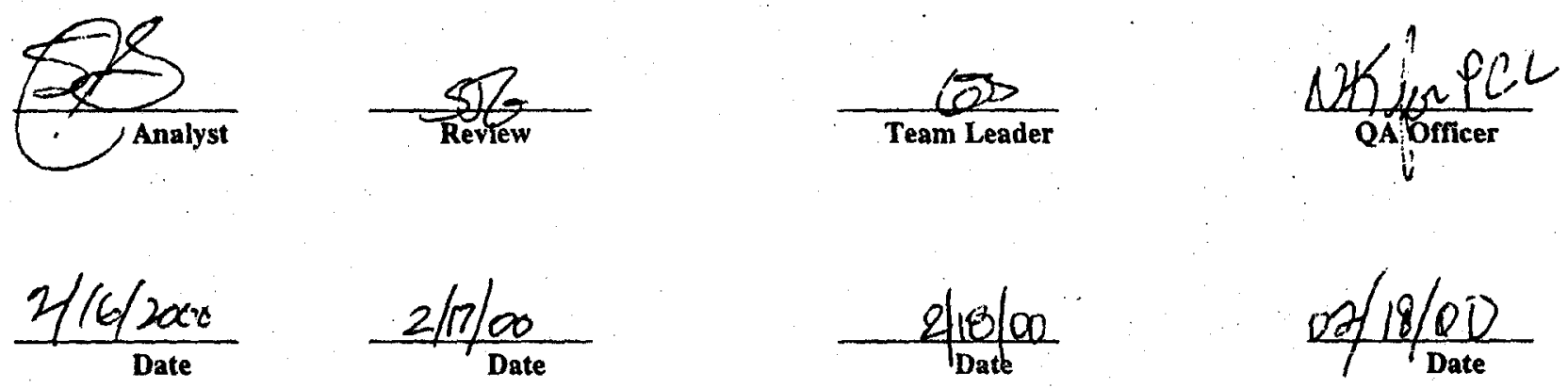

The control status of the preceeding data was evaluated using the standard statistical criteria set forth in Quality Assurance for Health and Environmental Chemistry: 1992, LA-12790-MS, Vol I, pp. 19-29.

"The reported uncertainties are at the 1 sigma confidence level unless otherwise stated." 
os Alamos

NATIONAL LABORATORY

Memorandum

Chemical Science and Technology

Responsible Chemistry for America

CST-9/Analytical Chemistry Sciences

Los Alamos, New Mexico 87545
To/MS: ESH-20/M887

From/MS: Nancy Lujan/MS K484

Phone/FAX: 5-6010/5-5982

Symbol: CST-9/00

Date: February 25, 2000

This is a Case Narrative for the following:

$\begin{array}{ll}\text { Submission ID } & : 100040337 \\ \text { Analysis } & : U(K P A) \text { in Ashed Bees }\end{array}$

\section{Introduction}

On September 20,1999, a set of Ashed Bee samples was delivered to the CST-9 radiochemistry section for the requested analysis.

\section{Analytical Results/Methodology}

The analytical results are presented as indicated by the terms on the Analytical Service Agreement. Each set of data will include sample identification information, the analytical results, and other information as required by the customer.

The analysis requested is: Uranium in Environmental Matrices - KPA. The specific procedure can be found either on line@ @ttp://cst.lanl.gov/docs, or in hardcopy form within the document entitled LA-10300-M, Vol. III, Method ANC337, R.0.

\section{Quality Control}

The appropriate quality control samples were analyzed with the samples.

\section{Comments}

This case narrative was generated to document the circumstances that were involved with the development if this data package. As part of the process to inform our customers of potential problems associated with specific methods, the KPA method has been found to be unreliable in some matrices due to the strong susceptibility of interference's from constituents commonly found in environmental samples. Alternate techniques available for the analysis of $U$ would be either ICP-MS or Isotopic Uranium analysis.

Samples were analyzed and reported. All Quality Control samples were In Control and reportable. I verify, to the best of my knowledge, that the listed results are both complete and technically correct.

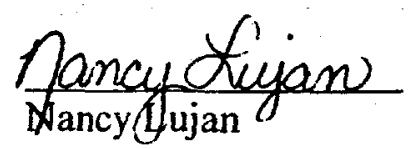




\begin{tabular}{|ll} 
Requester Name: & PHIL FRESQUEZ \\
Requester Group: & ESH-20 \\
\hline & \\
Mail Stop: & M887 \\
Requester Phone: & $667-0815$ \\
Requester Fax \#: & $667-0731$ \\
\hline
\end{tabular}

Customer Cost
Logged Date:
Study:
Analytical Serv

Component
U
Analysis Date
U
Analysis Date
U
Analysis Date

\section{DUPLICATE TASKS}

$\begin{array}{llll}\text { Sample Id } & \text { Task Id } & \text { Original Task } & \text { Component } \\ & \text { 300235204 } & & \begin{array}{l}\mathrm{U} \\ \text { Analysis Date }\end{array} \\ 200123221 & 300258941 & 300235204 & \mathrm{U} \\ & & & \text { Analysis Date }\end{array}$

\section{CUSTOMER SAMPLES}

\begin{tabular}{|c|c|c|c|c|c|c|}
\hline Sample Id & Task Id & Customer Id & Component & Result Value & Uncertainty & Units \\
\hline 200109136 & 300235204 & G-1 & $\mathbf{U}$ & 0.46 & 0.05 & ug/g \\
\hline & & & Analysis Date & 25-FEB-2000 & & DD-MON-YYYY \\
\hline 200109137 & 300235209 & G-2 & $\mathrm{U}$ & 0.39 & 0.04 & $\mathrm{ug} / \mathrm{g}$ \\
\hline & & & Analysis Date & 25-FEB-2000 & & DD-MON-YYYY \\
\hline 200109138 & 300235214 & C-1. & $\begin{array}{l}\mathrm{U} \\
\text { Analysis Date }\end{array}$ & $\begin{array}{l}0.31 \\
25-F E B-2000\end{array}$ & 0.03 & $\begin{array}{l}\text { ug/g } \\
\text { DD-MON-YYYY }\end{array}$ \\
\hline
\end{tabular}

Uncertainty

0.05

0.04

0.03

\begin{tabular}{|c|c|c|c|c|c|c|}
\hline Sample Id & Task Id & Customer Id & Component & Result Value & Uncertainty & Units \\
\hline 200109136 & 300235204 & G-1 & $\mathbf{U}$ & 0.46 & 0.05 & ug/g \\
\hline & & & Analysis Date & 25-FEB-2000 & & DD-MON-YYYY \\
\hline 200109137 & 300235209 & G-2 & $\mathrm{U}$ & 0.39 & 0.04 & $\mathrm{ug} / \mathrm{g}$ \\
\hline & & & Analysis Date & 25-FEB-2000 & & DD-MON-YYYY \\
\hline 200109138 & 300235214 & C-1. & $\begin{array}{l}\mathrm{U} \\
\text { Analysis Date }\end{array}$ & $\begin{array}{l}0.31 \\
25-F E B-2000\end{array}$ & 0.03 & $\begin{array}{l}\text { ug/g } \\
\text { DD-MON-YYYY }\end{array}$ \\
\hline
\end{tabular}

Due Date:

Screening Data:

22-NOV-99

NO SCREENING DATA REQUIRED

Logged by: $\quad$ APODACA

\section{Qualifier}

DD-MON-YYYY

DD-MON-YYYY

DD-MON-YYYY

\begin{tabular}{lll} 
Result Value & Uncertainty & Units \\
\hline 0.46 & 0.05 & $\begin{array}{l}\text { ug/g } \\
\text { 25-FEB-2000 }\end{array}$ \\
0.43 & 0.04 & DD-MON-YYYY \\
$25-$ FEB-2000 & & ug/g \\
& & DD-MON-YYYY
\end{tabular}


Method: GENERIC KPA Method Area: EH-ALPHA

Submission Id :

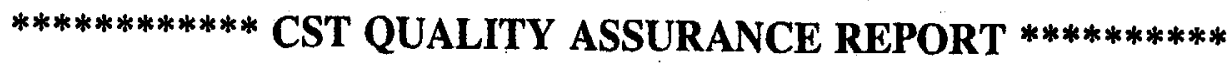

BLIND QC

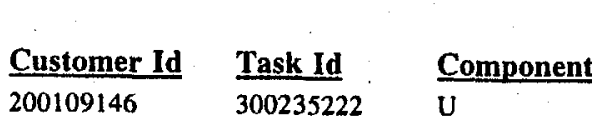

OPEN QC

Customer Id

00.38058

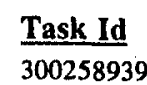

Component
Result

Value

0.38

Uncertainty

0.04

$\underline{\text { Units }}$

ug/g

Result

Value

10.74

Uncertainty

Units $\begin{array}{cc}\text { QC } & \text { QC } \\ \text { Value } & \text { Uncer }\end{array}$

$\frac{\text { Value }}{0.38} \quad \frac{\text { Uncerta }}{0.038}$

QC

ug/g IN CONTROL

METHOD BLANK

\begin{tabular}{|c|c|c|c|c|c|c|c|c|c|}
\hline$\frac{\text { Customer Id }}{00.22776}$ & $\frac{\text { Task Id }}{300258940}$ & $\frac{\text { Component }}{U}$ & $\begin{array}{l}\begin{array}{l}\text { Result } \\
\text { Value }\end{array} \\
0.00\end{array}$ & $\frac{\text { Uncertainty }}{0.01}$ & $\frac{\text { Units }}{\text { ug/g }}$ & $\begin{array}{c}\text { QC } \\
\text { Value } \\
0\end{array}$ & $\begin{array}{l}\text { QC } \\
\text { Uncertainty } \\
0\end{array}$ & $\begin{array}{c}\text { QC } \\
\text { units } \\
u \text { og }\end{array}$ & $\begin{array}{c}\text { QC } \\
\text { Evaluation }\end{array}$ \\
\hline
\end{tabular}




\section{Method: GENERIC KPA}

Method Area:
Submission Id :

100040337

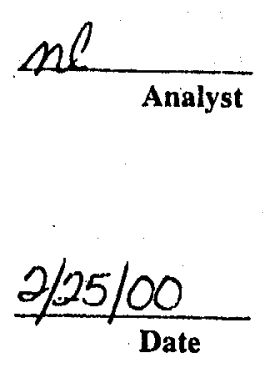

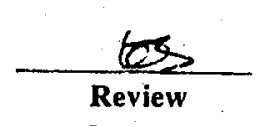

for 5

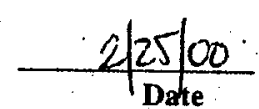

EH-ALPHA
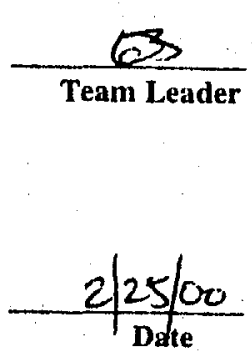

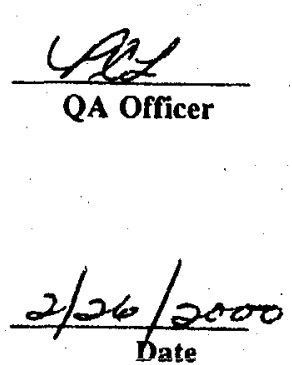
The control status of the preceeding data was evaluated using the standard statistical criteria set forth in Quality Assurance for Health and Environmental Chemistry:
1992, LA-12790-MS, Vol I, pp. 19-29.

"The reported uncertainties are at the 1 sigma confidence level unless otherwise stated." 